\title{
The Effect of Human Resource Management Practices on Corporate Performance: A Study of Graphic Communications Group Limited
}

\author{
Rosemond Boohene, $\mathrm{PhD}$ (Corresponding author) \\ School of Business \\ University of Cape Coast, Cape Coast \\ Tel: 233-20-710-5865 E-mail: rboohene@yahoo.com \\ Ernesticia Lartey Asuinura \\ School of Business \\ University of Cape Coast, Cape Coast
}

Tel: 233-33-213-7870_E-mail: ticialassuinura@yahoo.co.uk

\begin{abstract}
In developing economies such as Ghana, the influence of governments in state-owned entities renders many human resource management best practice principles ineffectual. Graphic Communications Group Limited (GCGL) is a state-owned entity. Its human resource practices can be crucial to its performance. The purpose of this study therefore was to assess whether GCGL's human resource management practices, particularly recruitment and selection, performance appraisal, remuneration, and training and development practices influence its performance. Simple random sampling was used to select one hundred employees from GCGL. T-tests were carried out to examine the relationship between the selected HR practices and corporate performance. The results revealed that, from the perceptions of the respondents, there exists a positive relationship between effective recruitment and selection practices, effective performance appraisal practices and GCGL's corporate performance. The research did not gather sufficient evidence to conclude on how remuneration, training and development practices influence GCGL's performance. The study recommends that the management of GCGL continues to ensure that the company's HR policy, effective recruitment and selection practices, as well as effective performance appraisal practices are upheld.
\end{abstract}

Keywords: Human Resource Management, Performance, Best Practices

\section{Introduction}

Increasing productivity in the public sector to match the levels of the private sector has been the call of the Public Services Commission in Ghana. According to Michie \& Oughton (2003), research suggests that closing the productivity gap between the private and public sectors will require increased investment in research and development, capital and people, improved education and training, and a modernised productive infrastructure. In a bid to improving productivity, Michie \& Oughton (2003) further suggest that there should be a continuous improvement in management practice, corporate governance and organisational design. Guest, Michie, Conway \& Sheenan (2003) also point out that a major challenge for modern organisations is the urge for increasing productivity and achieving a competitive advantage.

To achieve competitive advantage, Bohlander, Snell \& Sherman (2001) argue that while people have always been central to organisations, they have now taken on an even more central role in building a firm's competitive advantage. They reiterate the fact that success increasingly depends on the organisation's people-embodied know-how, which includes the knowledge, skills and abilities embedded in an organisation's employees. In the view of Schuler and Macmillan (1984), organisations best able to meet this challenge are those that can acquire and utilise valuable and scarce resources. Human resources fall into this category of resources, particularly if they are effectively deployed through appropriate human resource practices. One of the key tasks for an organisation, therefore, is the effective management of human resource. Research in Human Resource Management (HRM) has established that the success of any organisation is highly influenced by the calibre of its human resource (HR), which in turn, is affected by the organisation's human resource management practices.

The Graphic Communications Group Ltd (GCGL) is a state-owned media organisation, which is not on government subvention. Thus, it is required to generate its own funds, operate profitably and be able to pay at least $30 \%$ of profit as dividend to government annually. In the year 2003, the company underwent a corporate restructuring. Prior to this time, the company was barely breaking even and its ability to attract and retain skilled employees was limited. The HR department, which was headed by a non-HR professional, was also restructured with the recruiting of HR 
professionals into the department. The HR department was then tasked with reviewing the company's HR practices and recommending policy changes, where necessary. As part of the review, training programmes were organised for all categories of staff. Employees who lacked basic skills and qualifications and could not be retrained were laid off, whilst a rigorous recruitment process was instituted to attract skilled personnel for the various departments.

After 2003, the company's profit began growing and has continued ever since. Accordingly, it has paid annual dividends to government. This is in contrast to other state-owned media companies, which are struggling to break even. Since the restructuring, no research has been carried out to ascertain the effect of human resource management practices on the company's performance. The study therefore seeks to examine how the human resource management practices at GCGL have impacted on its performance.

\section{Research Framework}

Armstrong (2006) observes that the assumption underpinning the practice of HRM is that people are the organisation's key resource and organisational performance largely depends on them. Therefore, if an appropriate range of HR policies and processes are developed and implemented effectively, then HR will make a substantial impact on firm performance. Guest, Michie, Conway \& Sheenan (2003) also argue that the case for an association between human resource management and performance is based on two arguments. The first one being that the effective deployment of human resources offers one of the most powerful bases of competitive advantage. The second argument is that effective deployment of human resources depends on the application of a distinctive combination of practices, or the use of a consistent set of human resource practices. Additionally, Guest et al stress that there is a plausible case that human resource management will be more effective if it fits the business strategy of the firm.

Again, according to Collins \& Druten (2003) researchers have produced compelling evidence for the causal link between how people are managed and organisational performance. They argue that the effectiveness of human resource practices, particularly employee selection procedures, performance appraisals, rewards and benefits management, and employee training and development (the matching model of HRM) often have a direct bearing on organisational productivity and performance. Contributing to this assertion, Schuler and Macmillan (1984) present that, the result of effectively managing human resources is an enhanced ability to attract and retain qualified employees who are motivated to perform. To them, the benefits of having the right employees motivated to perform include greater profitability, low employee turnover, high product quality, lower production costs, and more rapid acceptance and implementation of corporate strategy. These invariably lead to higher productivity.

\subsection{Employee Recruitment and Selection and Corporate Performance}

Recruitment and selection involve getting the best applicant for a job. Huselid (1995) notes that recruitment procedures that provide a large pool of qualified applicants, paired with a reliable and valid selection regime, will have a substantial influence over the quality and type of skills new employees possess. Mullins (1999) also points out that the important thing is for some suitable plan to be used; and that the plan is appropriate to the essential or desired characteristics of the candidate. It is also necessary to comply with all legal requirements relating to employment and equal opportunities, to follow recommended codes of practice and to ensure justice and fair treatment for all applicants. Bohlander, Snell \& Sherman (2001) indicate that it is important for managers to understand the objectives, policies and practices used for selection. In that way, they can be highly involved in the process from the very beginning. Those responsible for making selection decisions should have adequate information upon which to base their decisions. Robbins (1991) further observes that an organisation's human resource policies and practices represent important forces for shaping employee behaviour and attitudes. The selection practices will determine who is hired. If properly designed, it will identify competent candidates and accurately match them to the job. The use of the proper selection device will increase the probability that the right person will be chosen to fill a slot. When the best people are selected for the job, productivity increases. Thus the first hypothesis states that:

H1: Effective recruitment and selection practices have a positive effect on corporate performance.

\subsection{Performance Appraisal and Corporate Performance}

The process of performance management, according to Mullins (1999), involves a continuous judgement on the behaviour and performance of staff. It is important that employees know exactly what is expected of them, and the yardstick by which their performance and results will be measured. A formalised and systematic appraisal scheme will enable a regular assessment of the individual's performance, highlight potential and identify training and development needs. Most importantly, an effective appraisal scheme can improve the future performance of staff. The appraisal scheme can also form the basis for a review of financial rewards and planned career progression. 
Bohlander et al (2001) suggest the following steps in conducting a performance appraisal: scheduling, preparing for the review and conducting the review. Scheduling the review involves notifying the employee ten days or two weeks in advance; asking the employee to prepare for the session by reviewing his or her performance, job objectives and development goals; and clearly stating that this will be the formal annual performance appraisal. Preparing for the review entails reviewing the performance documentation collected throughout the year while concentrating on work patterns that have developed; being prepared to give specific examples of above or below average performance; when performance falls short of expectations, determining what changes need to be made. If performance meets or exceeds expectations, discussing this and planning how to reinforce it; after the appraisal is written, setting it aside for a few days and then reviewing it again; and following whatever steps are required by the organisation's performance appraisal system.

According to Waal (2007), there is a clear and strong relation between organisational performance and the attention given to performance management and employee appraisal. The chances of actually achieving the objectives of the organisation are considerably improved when all management levels are in line with each other. In addition, this ensures that all organisation members know what is important for the organisation and what is expected from them. Everybody works under the same clear-structured regime. Waal further points out that, since the assessment and reward criteria are related to the strategic objectives of the organisation, it means that these human resource tools directly support the achievement of the organisational strategy. Therefore, the second hypothesis of this study is:

H2: Effective performance appraisal has a positive effect on corporate performance.

\subsection{Employee Rewards and Benefits Management and Corporate Performance}

Reward and benefits management, according to Armstrong (2006), is concerned with the formulation and implementation of strategies and policies, the purposes of which are to reward people fairly, equitably and consistently in accordance with their value to the organisation and thus help the organisation to achieve its strategic goals. It deals with systems (reward processes, practices and procedures) that aim to meet the needs of both the organisation and its stakeholders. Armstrong further presents that the philosophy of reward management recognises that if human resource management is about investing in human capital from which a reasonable return is required, then it is proper to reward people differently, according to their contribution (i.e. the return on investment they generate). Additionally, the philosophy of reward management also recognises that it must be strategic in the sense that it addresses longer-term issues relating to how people should be valued for what they do and what they achieve.

Reward strategies and the processes that are required to implement them have to flow from the business strategies. Therefore, rewarding will be affected by the business and the human resource strategies of the organisation, the significance attached to reward matters by top management, and the internal and external environment of the organisation. Armstrong (2006) further explains that the external environment includes the levels of pay in the labour market and submits that a reward system should consist of policies that provide guidelines on approaches to managing rewards; practices that provide financial and non financial rewards, and processes concerned with evaluating the relative size of jobs (job evaluation) and assessing individual performance (performance management). A reward system should also consist of procedures operated in order to maintain the system so as to ensure that it operates efficiently and flexibly, and provides value for money. The reward strategy should set out what the organisation intends to do in the longer term to develop and implement reward policies, practices and processes that will further the achievement of its business goals.

Waal (2007) suggests that, an employee's ability to see the connection between his or her work and the organisation's strategic objective is a driver of positive behaviour. This clarity is achieved by formulating and using personal objectives derived from strategy. Furthermore, uncertainty about the assessment criteria used for review and reward purposes also diminishes because employees know beforehand which criteria will be used. The identification of functional objectives and competencies helps improve the quality of the development of function descriptions and competency profiles. This will eventually result in better qualified and skilled personnel in the right positions. Finally, Waal is of the opinion that the implementation of personal objectives, personal targets and clear assessment criteria linked with a flexible reward structure, can lead to a positive cultural change. The commitment of employees to achieve the objectives of the organisation increases. Standards of what is good and what is wrong also become clear and consistent with each other. These ultimately lead to greater productivity and improved performance. Following from this, the third hypothesis of the study is that:

H3: Effective rewards and benefits management has a positive effect on corporate performance.

\subsection{Training and Development and Corporate Performance}

Training, according to Armstrong (2006) "is the use of systematic and planned instruction activities to promote learning" (p. 575). It involves the use of formal processes to impart knowledge and help people acquire the skills necessary for them to perform their jobs satisfactorily. The focus of training is on practical skills and is concerned 
with applying and implementing techniques and processes. Therefore, training is investing in people to enable them to perform well and empower them to make the best use of their natural abilities. The objectives of training, as identified by Armstrong are to develop the skills and competences of employees to improve their performance; to help people grow within the organisation in order for the organisation to meet its future human resource needs; to reduce the learning time for employees on appointment, transfer or promotion, and ensure that they become fully competent.

Development, according to Noe, Hollenbeck, Gerhart \& Wright (2004), means learning that is not necessarily related to the employee's current job. Instead, development prepares employees for other positions in the organisation and increases their ability to move into jobs that may not yet exist. Development may also help employees prepare for changes in their current jobs, such as changes resulting from new technology, work designs or customers. Development therefore is about preparing for change in the form of new jobs, new responsibilities, or new requirements. Noe et al further reiterate that employee development is a necessary effort of a company to improve quality and to meet the challenges of global competition and social change.

Lundy et al (2004) also observe that there is no all-embracing concept that brings together the processes of education, learning, training and development. However, it must be clear that they are inextricably linked. They share many common principles, e.g., learning theories, assessment and evaluation, and design of programmes, and so there is the need for synthesis. Lundy et al further reiterate that each individual matures over a lifetime and that development is the process, which can enable employees to reach a personal full potential. Development is therefore, for the most part, long term in focus. Education contributes to each individual's development by facilitating the attainment of mental powers, character and socialisation, as well as specific knowledge and skills.

Huselid (1995) also notes that providing formal and informal training experiences, such as basic skills training, on-the-job experience, coaching, mentoring and management development can further influence employees' development and hence, their performance. Training, when well done, will reflect in productivity, that is, productivity will increase, there will be reduction in accidents on the job and in the end profits of the organisation would be maximized; the ultimate goal of every employer. Dessler (2003) also sums up how training and development influences corporate performance by arguing that developing human capital through continuing training may increase the productive output from each employee either through improvement in skill level or through improvement in morale and job satisfaction. Consequently, the fourth hypothesis of this study is that:

H4: Training and development have a positive effect on corporate performance.

\section{Methodology}

The most common method of generating primary data is through survey (Zikmund 1999). He defines a survey as a research technique in which information is gathered from a sample of people through a questionnaire. Thus, because of the need to generate primary data to achieve the objectives of this study, survey research was adopted.

In addition, this study adopted the case study method. Kumekpor (2002) observes that case studies provide precedence as well as a source of reference for future cases. It also helps track the root cause of an issue or problem to a number of, hitherto, unsuspected factors and may result in probing into real meanings of phenomenon likely to be otherwise overlooked. Case studies also help in developing analytical and problem solving skills and allows for further exploration of solutions for complex issues. The method is also useful for research, especially in cases where the subject matter is of a unique nature rather than the normal or expected conditions. Because of the usefulness of the case study method, as enumerated above, the uniqueness of the circumstances of GCGL, and the fact that there is no clear single set of outcome on how specific HR practices impact on performance, the case study method of data collection was used for this study.

\subsection{Population and Sample}

The target population was the permanent workers of GCGL who number four hundred and sixty, and approximately three hundred of which are at the corporate Head office, which also houses the production plant. Simple random sampling was used to select 100 head office employees, made up of junior and senior staff. This was because given the circumstances, mainly time constraints and employees' willingness to answer the questionnaire; it was the only practical way of gathering the needed data for the research.

\subsection{Data Collection}

In gathering data, self-administered questionnaires were used to gather information from the employees. The rationale for using self administered questionnaires was to allow the respondents to answer at their own pace without taking them away from their work. In answering the questionnaire, the respondents were asked to indicate their responses to the questions on a five point Likert scale, ranging from 1 (strongly disagree) to 5 (strongly agree). 
The respondents had to indicate whether they strongly disagree, disagree, are neutral, agree or strongly agree to the question posed. The questionnaire was in seven segments. Segment A captured information about the respondents such as information regarding their department, whether they are junior, senior or management staff, their age, and length of service with the company. Segment B captured information on the company's recruitment and selection practices while segment $\mathrm{C}$ was on performance appraisal. Segment $\mathrm{D}$ tackled questions on the remuneration while segment $\mathrm{E}$ concentrated on training and development issues. Segments $\mathrm{F}$ and $\mathrm{G}$ were on human resource management practices and corporate performance issues respectively.

\section{Results and Discussions}

The study adopted the quantitative technique using the SPSS package in the analysis of information collected. The analysis involved the use of percentages and t-test to generate insights, make inferences and draw conclusions about the relationship that exists between HR practices and corporate performance.

\subsection{Preliminary Analysis}

Analyses of the demographic characteristics of respondents indicate that, $29 \%$ of them were females while $71 \%$ were males. Even though the sex of the respondents was skewed toward males, this imbalance is representative of the company's workforce as in Ghana, the majority of organizations are dominated by men, particularly when it includes a manufacturing plant. Moreover, $12 \%$ of the respondents are in the Audit department while $21 \%$ are in the Marketing department. $23 \%$ of respondents are employed in the Newspaper department, $16 \%$ and $18 \%$ in the Finance and Technical department respectively while $10 \%$ are employed in the HR department. Furthermore, $43 \%$ of the respondents fall within the age of 26 years to 35 years, while $33 \%$ are within the ages of 36 years to 45 years. Moreover, $41 \%$ had been employed for 5 years or less while $24 \%$ had worked with the company for between 6 to 10 years. The results indicate the youthfulness of workforce of the GCGL. This is expected considering the fact that the GCGL has undergone restructuring in 2003.

\subsection{Hypothesis Testing}

The $t$ test was used to test the hypotheses between the human resource management practices and corporate performance. The results are depicted in Table 1.

Place table here

The first hypothesis tested the effect of recruitment and selection practices on corporate performance. The t-test gives a positive figure of 8.252. In addition, the probability value (p-value) of the relationship between recruitment and corporate performance is 0.000 . This value is substantially smaller than the specified alpha value of 0.05 . Thus, the test of the hypothesis confirms that effective recruitment and selection practices have a positive effect on GCGL's corporate performance. This positive significant relationship means that GCGL should always ensure that the best candidate is recruited whenever vacancies arise, thus minimising employee ineffectiveness and its associated costs.

In testing the effect of performance appraisal practices on corporate performance, the t-test yields 7.790 and the probability value (p-value) of the relationship between performance appraisal and corporate performance is 0.000 . Because the t-test is positive and the p-value is 0.000 , lower than the level of significance, it shows that that effective performance appraisal practices have a positive effect on GCGL's corporate performance. The results may be that employees of GCGL are satisfied with the performance appraisal system and therefore will always strive to bring out the best in terms of their contribution to financial performance.

The t-test for the third hypothesis yields a result of -1.042 and a p-value of 0.300 which is greater than the alpha value of 0.05 . This suggests that it cannot be concluded that effective reward and benefits management has a positive effect on corporate performance. In effect, the research did not observe evidence to support the hypothesis that effective reward and benefits management practices have a positive effect on GCGL's corporate performance. As the review of the literature showed, research has established that although the value of a company's human resource assets may not show up directly on its balance sheet, it nevertheless, has tremendous impact on an organisation's performance. These findings attest to the view expressed by Stup et al (2005) that the relationships between firm level performance and HRM are complex and not always positive and also in public organisations remunerations are usually not commensurate with output.

The fourth hypothesis examined the effect of training and development on corporate performance. The t-test yields a result of -0.650 and a $\mathrm{p}$-value of 0.517 . This suggests that it cannot be concluded that effective training and development practices have a positive effect on corporate performance. In effect, the research did not observe evidence to support the hypothesis that effective training and development practices have a positive effect on GCGL's corporate performance. This may be because GCGL is a public organisation and therefore although workers go through training and development programmes they are not motivated to apply what they have learnt as promotion is may also be based on long service not on output. 


\section{Conclusions and Recommendations}

In sum, GCGL's financial performance could be explained by its effective recruitment and selection practices and performance appraisal practices. As the review of the literature showed, research has established that although the value of a company's human resource assets may not show up directly on its balance sheet, it nevertheless, has tremendous impact on an organisation's performance. However, there was insufficient evidence to show that GCGL's remuneration practices as well as its training and development practices contribute positively towards its corporate performance, as perceived by the respondents.

Based on the findings of this research, it is recommended that the management of GCGL continues to ensure that the HR policy, which is a result of the corporate strategy to use human resource, among others, to achieve outstanding performance every year, is upheld. In addition, copies of the HR policy should be made available to all employees to ensure widespread dissemination and application of the policies. Management should continue to ensure that the recruitment and selection process is, and seen to be fair. There should be measures that will ensure that all recruitment and selection practices adhere to the standards and policies of the company since effective recruitment and selection practices will ensure positive financial returns for the company, either through ensuring effectiveness on the part of employees, or minimisation of costs associated with training and retraining of employees.

The management of GCGL should also ensure that performance appraisal is taken seriously and policy standards rigorously adhered to because this study has established that there is a clear and strong relation between its performance and the attention given to performance management and employee appraisal. Management must also ensure that training and development programmes are relevant for current and future employee performance on the job. Training and development programmes must therefore be strategically planned. Further, management must ensure that there is a fair balance between financial and non-financial rewards when designing, reviewing and implementing a reward strategy.

\section{Limitations and Directions for Future Research}

This research is subject to the usual limitations of survey research. First, the research focused on a single organisation and only four human resource management practices. Secondly the respondents were only based at the head office and not the other regions where the firm has branches. Finally, the research did not gather enough evidence to conclude on the effect of some HRM practices on corporate performance. Thus, future research could also be replicated to other sectors, including a comparison between the private and public sector. In addition, the research framework and hypothesis developed for this study could be expanded to include the influence of other HR practices and environmental factors on corporate performance.

\section{References}

Anthony, W. P., Perrewe, P. L. \& Kacmar, K. M. (1999). Human resource management. Orlando: The Dryden Press.

Armstrong, M. \& Murlis, H. (1994). Reward management. London: Kogan Page.

Armstrong, M. (2006). A handbook of human resource management practice. London: Kogan Page.

Bailey, T. (1993). Discretionary effort and the organisation of work: employee participation and work reform since Hawthorne. Retrieved

from

http://www.emeraldinsight.com/Insight/html/Output/Published/EmeraldFullArticle/Pdf/2

Becker, B. \& Gerhart, B. (1996). The impact of human resource management on organizational performance: Progress and prospects. Retrieved from http:/www.ilr.cornell.edu/depts /cahrs/downloads/ pdfs/working papers/WP04-09.pdf.

Bohlander, G., Snell, S. \& Sherman, A. (2001). Managing human resources. New York: South- Western College.

Cannavos, G. C. \& Miller, D. M. (1995). Modern business statistics. Belmont: Wadsworth.

Collins, R. \& Druten, K. van (2003). Human resource management practices. Retrieved from http://www.edu.au/agsm/web.agsm.nsf/AttachmentByTitle/CCHREPORT2003/\$FILE/C

Dessler, G. (2003). Human resource management. New Jersey: Prentice Hall.

Flick, U. (2006). An introduction to qualitative research. London: Sage.

Guest, D. E., Michie, J., Conway, N., \& Sheenan, M. (2003). Human resource management and corporate performance in the UK. British journal of industrial relations, 41(2), $291-314$.

Hair, J. F., Bush. R. P. \& Ortinau, D. J. (2003). Marketing research. Boston: McGraw- Hill.

Hodgetts, R. M. (2002). Modern human relations at work. Ohio: South-Western College. 
Huselid, M. A. (1995). The impact of human resource management practices on turnover, productivity and corporate financial performance. Retrieved from http://www.markhuselid.com/articles.html.

Johnson, G., \& Scholes, K. (1999). Exploring corporate strategy. London: Prentice Hall.

Kumekpor, T. K. B. (2002). Research methods and techniques of social research. Accra: Sonlife Press.

Lundy, O., \& Cowling, A. (2004). Strategic human resource management. London: Thomson Learning.

Mann, P. S. (1995) Statistics for business \& economics. New York: John Wiley \& Sons.

Mason, R. D., Lind, R., \& Marchal, B. (1999). Statistical techniques in business \& economics. Boston: Irwin McGraw-Hill.

Mendenhall, W., \& Reinmuth, J. E. (1986). Statistics for management \& economics. Boston: PWS.

Meyer, J. P., \& Allen, N. J. (1997). Commitment in the workplace: Theory, research and application. California: Sage Publications. Retrieved from http://www.en.wikipedia.org/wiki/Organizational_commitment.

Michie, J., \& Oughton, C. (2003). HRM, employee share ownership and corporate performance: research and practice in human resource management. Retrieved http://www.unibz.it/web4archiv/objects/pdf/standard/cvoughton.christine.pdf.

Mullins, J. L. (1999). Management and organisational behaviour. London: Prentice Hall.

Noe, R. A., Hollenbeck, J. R., Gerhart, B. \& Wright, P. M. (2004). Fundamentals of human resource management. Toronto: McGraw-Hill.

Pearce, J. A., \& David, F. (1987). Corporate mission statements and the bottom line. Retrieved from http://www.emeraldinsight.com/Insight/html/Output/Published/EmeraldFullTextArticle/Pdf/0250180203_ref.

html.

Pelosi, M. K., Sandifer, T. M. \& Serkaran, U. (2001). Research and evaluation for business. Cypress: John Wiley \& Sons.

Pfeffer, J. (1998). The human equation: Building profits by putting people first. Boston: Harvard Business School Press.

Robbins, S. P. (1991). Organizational behaviour: concepts, controversies and applications. New Jersey: Prentice Hall.

Schuler, R. S. \& Macmillan, I. C. (1984). Gaining competitive advantage through human resource management practices. Retrieved from http://www.rci.rutgers.edu/ schuler/ainpages/gainingCompadvantagehrmpractices.

Stup, R. E., Hyde, J., \& Holden, L. A. (2005). Relationships between selected Human resource management practices and dairy farm performance. Retrieved from http://www.ncbi.nlm.nih.gov/pubmed/16507709.

Thompson, J. L. (2004). Strategic management. London: Thomson Learning.

Twumasi, P. A. (1986). Social research in rural communities. Accra: Ghana Universities Press.

Waal, A. A. de (2007). Strategic performance management: A managerial and behavioural approach. New York: Palgrave Macmillan.

Werther, W. B. \& Davis, K. (1996). Human resources and personnel management. New York: McGraw-Hill.

Yin, R. K. (2003). Applications of case study research. London: Sage.

Zikmund, W. G. (1997). Exploring marketing research. Orlando: The Dryden Press.

Zikmund, W. G. (1999). Essentials of marketing research. Orlando: The Dryden Press.

Table 1. Effects of Human Resource Management Practices on Corporate Performance

\begin{tabular}{|l|l|l|l|l|l|}
\hline Human resource practices and corporate performance & Mean & $\begin{array}{l}\text { Standard } \\
\text { deviation }\end{array}$ & $\begin{array}{l}\text { Standard error } \\
\text { of mean }\end{array}$ & t value & $\begin{array}{l}\text { p value (two } \\
\text { tailed) }\end{array}$ \\
\hline Recruitment and selection and corporate performance & 5.330 & 6.459 & 0.646 & 8.252 & 0.000 \\
\hline Performance appraisal and corporate performance & 4.560 & 5.854 & 0.585 & 7.790 & 0.000 \\
\hline Rewards and benefits and corporate performance & -.620 & 5.952 & 0.595 & 1.042 & 0.300 \\
\hline Training and development and corporate performance & -0.410 & 6.310 & 0.631 & -0.65 & 0.517 \\
\hline
\end{tabular}

